\title{
Pengembangan Digibook Barisan dan Deret Berbasis Anyflip untuk Mengeksplor Kemampuan Berpikir Komputasional Peserta Didik
}

\author{
Fanny Ahmad Fauzi ${ }^{1}$, Nani Ratnaningsih ${ }^{2}$, Puji Lestari ${ }^{3}$ \\ ${ }^{123}$ Magister Pendidikan Matematika Universitas Siliwangi \\ J1. Siliwangi No. 24, Tawang, Tasikmalaya, Indonesia \\ fnnahmad@gmail.com
}

\begin{abstract}
The aims of this study develop an Anyflip-based digibook on sequences and series material to explore students' computational thinking and determine the quality of the effectiveness of computational thinking skills after using a digibook. The method used in this research is the research and development method (Research \& Development) with the ADDIE development model which goes through several stages, namely Analyze, Design, Develop, Implementation, and Evaluation to get a valid and usable product. The subjects in this study were 2 material experts, 2 media experts, 5 individual trial students, 3 individual trial teachers and 20 students of class XI MIPA 6 SMAN 1 Talaga. Data collection techniques in this study were using validation sheets for media experts and material experts, user response questionnaires for individual trials given to 5 students of class XI SMAN 1 Talaga and 3 mathematics teachers, limited trial questionnaires given to participants. students of class XI SMAN 1 Talaga, then pretest and posttest computational thinking. Based on the results of the research, the row and series digibook is valid and can be used from media experts and material experts. The results of individual trials and limited trials obtained the "good" category. The results of the effect size (ES) test obtained a value of 1.03 in the "strong effect" category. Therefore, it can be concluded that the sequence and series digibook based on anyflip is valid and can be used by students, and the quality of the effectiveness of the sequence and series digibook has a strong effect.
\end{abstract}

Keywords: Digibook, Anyflip, computational thinking

\begin{abstract}
Abstrak
Penelitian ini bertujuan untuk mengembangkan digibook berbasis Anyflip pada materi barisan dan deret untuk mengeksplor berpikir komputasional peserta didik dan mengetahui kualitas efektivitas kemampuan berpikir komputasional setelah menggunakan digibook. Metode yang digunakan dalam penelitian ini yaitu metode penelitian dan pengembangan (Research \& Development) dengan model pengembangan ADDIE yang melalui beberapa tahap yaitu Analyze, Design, Develop, Implementation, and Evaluation untuk mendapatkan produk yang valid dan dapat digunakan. Subjek pada penelitian ini adalah 2 orang ahli materi, 2 orang ahli media, 5 orang peserta didik uji coba perorangan, 3 orang guru uji coba perorangan dan 20 orang peserta didik kelas XI MIPA 6 SMAN 1 Talaga. Teknik pengumpulan data pada penelitian ini adalah menggunakan lembar validasi untuk ahli media dan ahli materi, angket respon pengguna untuk uji coba perorangan yang diberikan kepada 5 orang peserta didik kelas XI SMAN 1 Talaga dan 3 orang guru matematika, angket uji coba terbatas yang diberikan kepada peserta didik kelas XI SMAN 1 Talaga, kemudian pretest dan posttest berpikir komputasional. Berdasarkan hasil penelitian, digibook barisan dan deret valid dan dapat digunakan dari ahli media dan ahli materi. Hasil uji coba perorangan dan uji coba terbatas memperoleh kategori "baik". Hasil uji effect size (ES) memperoleh nilai 1.03 dengan kategori "strong effect". Oleh karena itu, dapat disimpulkan bahwa digibook barisan dan deret berbasis anyflip valid dan dapat digunakan oleh peserta didik, dan kualitas efektivitas digibook barisan dan deret berpengaruh kuat.
\end{abstract}

Kata kunci: Digibook, Anyflip, berpikir komputasional

Copyright (c) 2021 Fanny Ahmad Fauzi, Nani Ratnaningsih, Puji Lestari

$\triangle$ Corresponding author: Fanny Ahmad Fauzi

Email Address: fnnahmad@gmail.com (Jl. Siliwangi No. 24, Tawang, Tasikmalaya, Indonesia)

Received 26 October 2021, Accepted 22 December 2021, Published 03 January 2022

\section{PENDAHULUAN}

Pada pembelajaran daring seperti saat ini, pendidik dan peserta didik dituntut untuk lebih melek teknologi agar tidak kesulitan dalam mengoperasikan berbagai media pembelajaran daring. Sesuai dengan pernyataan Ratnaningsih, Ni'mah \& Hidayat (2021) yang menyatakan bahwa integrasi 
teknologi adalah kunci keberhasilan selama proses pembelajaran. Dengan menguasai berbagai teknologi, pendidik dapat menggunakan beragam media pembelajaran daring yang efektif dan efisien sehingga pembelajaran daring dapat berjalan sesuai dengan yang diharapkan pendidik. Menurut Vygotsky dalam Taber (2018) untuk mencapai kesuksesan (dalam hal ini kesuksesan belajar) perlu adanya scaffolding atau dukungan. Scaffolding memiliki potensi untuk mendukung pembelajaran yang dapat memfasilitasi pengembangan peserta didik untuk mencapai kesuksesan belajar. Scaffolding adalah metode pembelajaran dengan memberikan dukungan belajar secara terstuktur. Scaffolding yang dapat membantu peserta didik dalam belajar adalah penggunaan media pembelajaran.

Pemilihan media pembelajaran yang tepat dapat membantu siswa belajar secara efisien (Sopian \& Afriansyah, 2017). Selain itu, menurut Patmawati, Ratnaningsih \& Hermanto (2016) untuk memudahkan peserta didik belajar mandiri, penggunaan media pembelajaran merupakan salah satu alternatif dalam proses pembelajaran menjadi lebih baik. Oleh karena itu, diperlukan sebuah media pembelajaran matematika yang mudah dioperasikan dan menggunakan perangkat yang dimiliki peserta didik. Pemanfaatan media pembelajaran yang menarik akan memudahkan pendidik dalam mentransfer informasi. Selain itu, media pembelajaran yang digunakan haruslah fleksibel agar peserta didik dapat menggunakan media tersebut kapanpun dan dimanapun ketika membutuhkannya. Salah satu media pembelajaran berbasis smartphone yang menarik dan fleksibel adalah digital book atau buku digital atau yang lebih dikenal dengan e-book. Mayoritas e-book disimpan dalam bentuk PDF (portable document format), dan memerlukan ruang khusus untuk menyimpannya. Selain itu, e-book yang biasa digunakan tidak memuat konten digital seperti video. Berbeda dengan e-book pada umumnya, digital book yang dikembangkan penulis adalah digital book yang disimpan dalam bentuk html5 yang memuat konten video seperti video dan terdapat kuis online, kemudian di publish secara online dan dapat dibuka menggunakan sebuah link yang dibuat secara otomatis oleh sistem. Selain itu, digital book yang dikembangkan adalah digibook barisan dan deret untuk mengeksplor berpikir komputasional peserta didik. Penyusunan materi, contoh soal, latihan dan kuis disesuaikan dengan indikator-indikator berpikir komputasional sehingga dapat mengeksplor berpikir komputasional.

Penggunaan media interaktif dalam pembelajaran matematika di kelas diharapkan dapat menarik minat dan memotivasi peserta didik untuk tingkatkan prestasinya (Ratnaningsih, 2016). Media pembelajaran interaktif seperti digital book dapat memudahkan peserta didik dalam memahami materi yang dianggap sulit. Salah satu materi yang sulit dipahami oleh peserta didik adalah materi barisan dan deret. Hal ini sejalan dengan pendapat Hasanah, Nugraheni \& Purwoko (2020) peserta didik mempunyai kendala dalam mengasosiasi atau menalar yaitu menentukan banyaknya suku dan menentukan rumus barisan dan deret yang digunakan dalam penyelesaian permasalahan. Nopriana, Firmasari \& Tonah (2016) yaitu dalam menyelesaikan permasalahan barisan dan deret geometri pada tahap pemahaman konsep sebagian besar siswa mengalami kesulitan dalam memahami masalah. 
Materi barisan dan deret berkaitan dengan pola. Salah satu kemampuan untuk menggali lebih dalam mengenai pengenalan sebuah pola adalah berpikir komputasional. Menurut CSTA dalam Asbell-Clarke et al (2021) indikator berpikir komputasional adalah dekomposisi, pengenalan pola, generalisasi pola dan abstraksi dan berpikir algoritma. Oleh karena itu, dengan berpikir komputasional peserta didik dapat lebih mudah dalam mengenali dan menggeneralisasikan sebuah pola pada materi barisan dan deret. Untuk mengeksplor berpikir komputasional, digibook yang dikembangkan disusun berdasarkan indikator-indikator bepikir komputasional.

Berbagai permasalahan banyak ditemukan selama pembelajaran daring di era pandemik seperti saat ini. Salah satunya adalah banyak peserta didik yang tidak mengikuti pembelajaran daring, khususnya pada pelajaran matematika. Berdasarkan hasil wawancara terhadap salah satu guru matematika di SMA Negeri 1 Talaga, pembelajaran daring tidak berjalan secara optimal, meskipun telah menggunakan media pembelajaran daring seperti youtube, whatsapp, google classroom, edmodo dan kaizala, namun media tersebut tidak cukup membantu peserta didik untuk belajar secara mandiri. Hal ini disebabkan keterbatasan guru dalam menerangkan materi matematika dalam pembelajaran daring melalui whatsapp karena keterbatasan fitur whatsapp untuk menunjang pembelajaran, selain itu jika menggunakan zoom meeting atau google meet beberapa guru merasa kesulitan dalam memahami fitur yang tersedia, oleh karena itu penerimaan beberapa siswa masih dirasa sulit. Hal ini sejalan dengan pendapat Asmuni (2020) yang menyatakan kemampuan guru terbatas dalam menggunakan teknologi pada pembelajaran daring. Sementara itu, digibook yang dikembangkan didesain agar peserta didik dapat belajar mandiri, karena pada digibook ini, terdapat materi, latihan soal, audio, video dan kuis dalam satu digibook. Selain itu, penyajian materi yang dirancang secara sederhana agar mudah dipahami, juga terdapat audio dan video penjelasan materi yang dapat membantu peserta didik agar lebih memahami materi yang diberikan guru.

Beberapa penelitian telah mengembangkan digibook sebagai media pembelajaran [Angriani et al., 2020; Pixyoriza, Netriwati \& Sugiharta, 2019; Munandar \& Rizki, 2019; Sari, 2016] yang menggunakan aplikasi flip PDF Profesional, Kvisoft Flipbook, Sigil dan flipbook maker. Berbeda dengan penelitian ini yang menggunakan aplikasi Anyflip. Berbagai penelitian tentang barisan dan deret pun banyak dilakukan, seperti penelitian [Hasanah et al., 2020; Sanusi et al., 2020; Firdaus, Nisa \& Nadhifah, 2019; dan Setyadi \& Qohar, 2017], namun penelitian tersebut bukan pengembangan media belajar digital book. Begitupun penelitian tentang berpikir komptasional telah dilakukan seperti penelitian [Cahdriyana \& Richardo, 2020; Fajri, Yurniwati \& Utomo, 2019; Zhong, Wang, Chen \& Li, 2016; dan Lei, Chiu, Li, Wang \& Geng, 2020], namun bukan pada materi barisan dan deret dan bukan pengembanan pada digibook. Berbeda dengan penelitian pengembangan ini yang mengembangkan media pembelajaran berbentuk digibook pada materi barisan dan deret dengan menggunakan aplikasi anyflip untuk mengeksplor berpikir komputasional peserta didik. 


\section{METODE}

Jenis penelitian yang digunakan dalam penelitian ini adalah metode penelitian dan pengembangan (Reseach and Develovment) dengan menggunakan model ADDIE. Menurut Sugiyono (2017) metode penelitian dan pengembangan adalah metode penelitian yang digunakan untuk menghasilkan produk tertentu dan menguji keefektifan produk tersebut. Pada penelitian ini produk yang menghasilkan adalah digibook matematika pada materi barisan dan deret untuk mengeksplor berpikir komputasional peserta didik dan menguji efektivitas. Model yang digunakan dalam pengembangan ini adalah model ADDIE (Branch, 2010) yang terdiri dari 5 tahapan yaitu: (1) Analyze (analisis), pada tahap ini dilakukan analisis media pembelajaran, materi pelajaran, peserta didik dan guru melalui angket dan wawancara. (2) Design (perancangan), pada tahap ini mengumpulkan data, membuat flowchart, dan membuat storyboard, mempersiapkan instrument tes, lembar validasi ahli media dan ahli materi, dan angket respon pengguna. (3) Develop (pengembangan), pada tahap ini menghasilkan produk sesuai rancangan, melakukan uji ahli media, dan uji ahli materi, (4) Impelementation (implementasi), pada tahap ini melakukan uji coba perorangan dan uji coba terbatas. Uji coba perorangan dilakukan terhadap 3 orang guru matematika dan 5 orang peserta didik, sementara uji coba terbatas dilakukan terhadap 20 orang peserta didik kelas XI MIPA 6 SMAN 1 Talaga, dan (5) Evaluation (evaluasi), pada tahap ini melakukan penyempurnaan produk apabila masih terdapat kekurangan dan kelemahan.

Teknik pengumpulan data pada penelitian ini yaitu angket, wawancara, lembar validasi dan tes berpikir komputasional. Pemberian angket pada tahap analisis dilakukan untuk menganalisis media pembelajaran, materi pelajaran, peserta didik dan guru. Kemudian dilakukan wawancara untuk memperkuat dan memperjelas hal-hal yang yang terdapat pada hasil pengisian angket. Validasi dilakukan terhadap ahli materi dan ahli media untuk menghasilkan produk yang valid. Pemberian angket pada tahap implementasi dilakukan untuk melihat respon pengguna yaitu peserta didik dan guru untuk mengetahui kualitas efektifitas produk yang dikembangkan. Instrumen yang digunakan pada penelitian ini adalah angket untuk menganalisis media pembelajaran, materi pelajaran, peserta didik dan guru, lembar validasi untuk ahli materi dan ahli media, angket respon pengguna, dan soal tes berpikir komputasional. Semua instrumen yang digunakan dalam penelitian ini sudah layak digunakan. Teknik analisis data dalam penelitian ini adalah deskriptif kualitatif, yaitu mendeskripsikan hasil angket, dan wawancara pada tahapan analisis, mendeskripsikan hasil validasi ahli media dan ahli materi untuk menentukan kevalidan produk, mendeskripsikan hasil angket respon pengguna, serta melakukan perhitungan uji Effect Size (ES) untuk mengetahui kualitas efektivitas produk yang dikembangkan. 


\section{HASIL DAN DISKUSI}

Hasil yang diperoleh dalam penelitian ini yaitu suatu produk digibook barisan dan deret untuk mengeksplor berpikir komputasional dan data hasil pretest dan postest berpikir komputasional peserta didik. Tujuan dari penelitian ini adalah untuk membahas secara komprehensif mengenai prosedur pengembangan digibook barisan dan deret berbasis Anyflip untuk mengeksplor berpikir komputasional bagi peserta didik, serta untuk mengetahui kualitas efektivitas berpikir komputasional peserta didik setelah menggunakan digibook barisan dan deret berbasis Anyflip. Berikut prosedur pengembangan dengan menggunakan model ADDIE dalam menghasilkan digibook barisan dan deret untuk mengeksplor berpikir komputasional.

Analyze (Analisis)

Tahap analisis dilakukan untuk mengidentifikasi suatu permasalahan dan kebutuhan yang diperoleh melalui hasil angket dan wawancara. Banyak kendala yang dihadapi oleh guru dalam pembelajaran daring, diantaranya adalah guru masih kesulitan dalam mengontrol proses belajar peserta didik dan meningkatkan partisipasi peserta didik dalam KBM. Selain itu, masih banyak peserta didik yang tinggal di daerah yang tidak terjangkau sinyal, minimnya kuota yang dimiliki peserta didik, motivasi peserta didik dalam pembelajaran, sulitnya komunikasi dua arah jika ada materi yang kurang dipahami. Sumber belajar buku paket dan modul dirasa masih kurang efektif karena tidak fleksibel untuk digunakan diberbagai tempat. Sementara buku elektronik dalam bentuk pdf memerlukan ruangan khusus dalam smartphone dan terkadang peserta didik lupa lokasi penyimpanan file pdf tersebut.

\section{Design (Desain)}

Tahap selanjutnya adalah desain, pada tahap ini berisi rencana yang akan dilakukan dalam penelitian dan pengembangan. Kegiatan yang dilakukan pada tahap ini adalah (a) membuat flowchart atau menyusun sebuah alur pembuatan media pembelajaran yang kemudian dijadikan dasar dalam pengembangan storyboard, (b) membuat Storyboard atau rancangan pembuatan digibook barisan dan deret yang berisi detail gambaran digibook, (c) mempersiapkan materi, audio, video, contoh soal, dan latihan soal, (d) mempersiapkan instrumen tes berdasarkan indikator berpikir komputasional, (e) merancang lembar penilaian dan angket respon pengguna yang digunakan sebagai alat pengumpulan data validasi media, validasi materi, dan respon peserta didik untuk mengetahui kelayakan digibook barisan dan deret yang dikembangkan.

\section{Development (Pengembangan)}

Tahap selanjutnya adalah development, pada tahap ini merupakan tahap pengembangan dengan kegiatan membuat dan memodifikasi digibook untuk mencapai tujuan yang telah ditentukan sesuai dengan rancangan yang telah dibuat. Setelah itu, digibook diuji oleh ahli (validator) materi dan media pembelajaran agar produk yang dihasilkan memenuhi standar dan kebutuhan siswa. Awal kegiatan yang dilakukan pada tahap ini adalah mempersiapkan komponen dalam pembuatan digibook 
yaitu menentukan background untuk setiap materi, menentukan jenis font dan ukuran, mencari gambar dan icon. Kemudian, menghasilkan produk digibook barisan dan deret untuk mengeksplor berpikir komputasional. Pembuatan desain digibook dilakukan pada aplikasi power point, seperti membuat tampilan background, menata gambar-gambar, tulisan, icon-icon dan lain-lain, kemudian diconvert ke pdf sebelum di edit pada aplikasi anyflip. Selanjutnya pada aplikasi anyflip mulai pengeditan digibook seperti mengaktifkan icon-icon, link, menginput video dan audio, mengedit volume suara, mengedit ukuran digibook dan lain-lain. Gambar dan icon di dapat dari google, sebelum diinput, gambar tersebut di hapus terlebih dahulu backgroundnya secara online agar gambar yang dihasilkan lebih menarik.

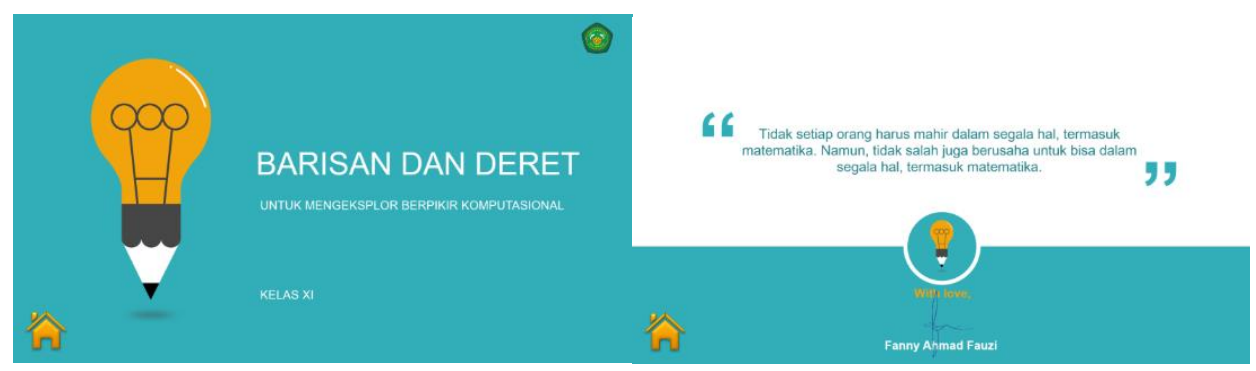

Gambar 1. Cover Digibook

Gambar 2. Quotes

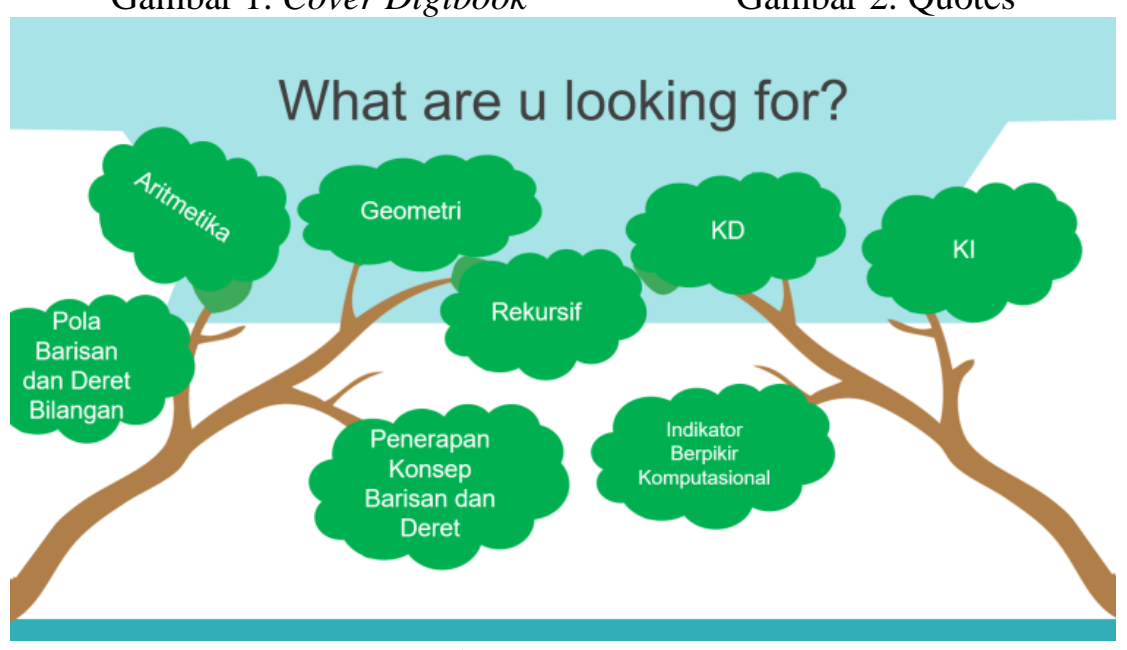

Gambar 3. Menu Home

Cover digibook ditunjukan pada gambar 1 yang terdapat pada halaman awal digibook. Kemudian terdapat quotes untuk memotivasi peserta didik agar terus belajar dengan giat yang ditampilkan pada Gambar 2 yang terdapat pada halaman 2. Selanjutnya pada halaman 3 terdpaat home yang berisi KI, KD, indikator berpikir komputasional dan sub bab materi seperti pada Gambar 3. Ketika mengklik salah satu menu tersebut, maka akan ditujukan ke halaman yang dipilih. Tampilan halaman KI dan KD ditunjukan pada gambar 4. Kemudian tampilan indikator berpikir komputasional sebagai pengantar dalam penyelesaian soal ditampilkan pada Gambar 5. KI, KD dan indikator berpikir komputasional menjadi dasar peneliti dalam mengembangkan digibook barisan dan deret ini. Setiap halaman pada digibook ini terdapat menu home, sehingga memudahkan pengguna jika mengganti materi yang akan dipelajari. 


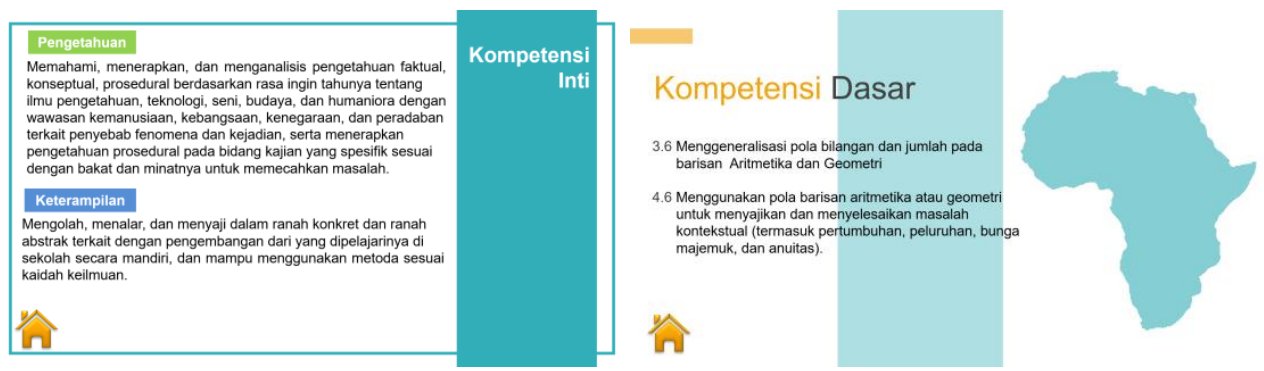

Gambar 4. Tampilan KI dan KD
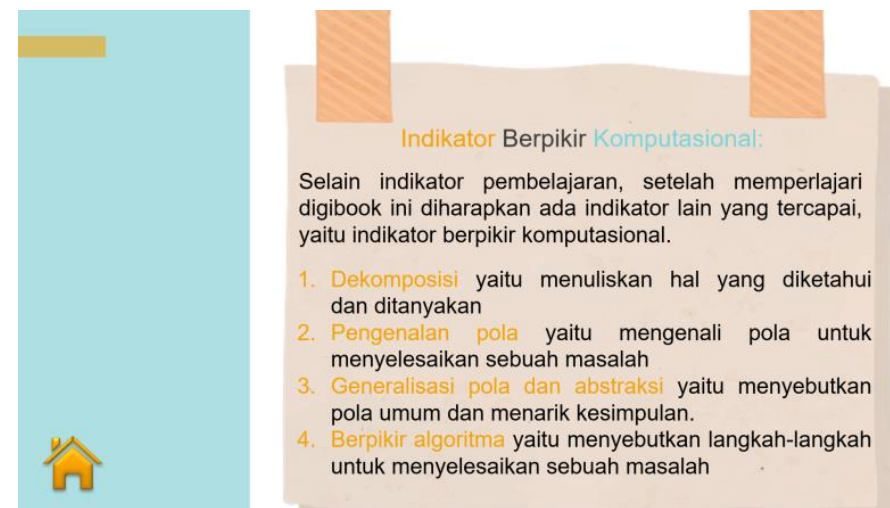

Gambar 5. Indikator Berpikir Komputasional

Ketika memilih salah satu sub bab materi pada gambar 4.3 maka akan diarahkan ke halaman menu lanjutan yang terdiri dari pilihan materi, video dan Latihan soal. Kecuali khusus untuk sub bab barisan dan deret bilangan tidak ada menu lanjutan karena leih efektif tidak menggunakan menu lanjutan. Berikut adalah tampilan dari menu barisan dan deret bilangan ditunjukan pada Gambar 6 . Sementara untuk materi lain akan ditujukan ke menu lanjutan yang terdiri dari judul materi, pilihan materi, video dan Latihan seperti pada Gambar 7. Ketika memilih menu materi maka akan dilanjutkan ke pilihan materi yang ditunjukan pada Gambar 8. Pada halaman pilihan materi dan pilihan video, selain terdapat tombol home yang ditujukan ke menu utama, juga terdapat tombol buku yang akan ditujukan ke menu materi seperti pada gambar 7.

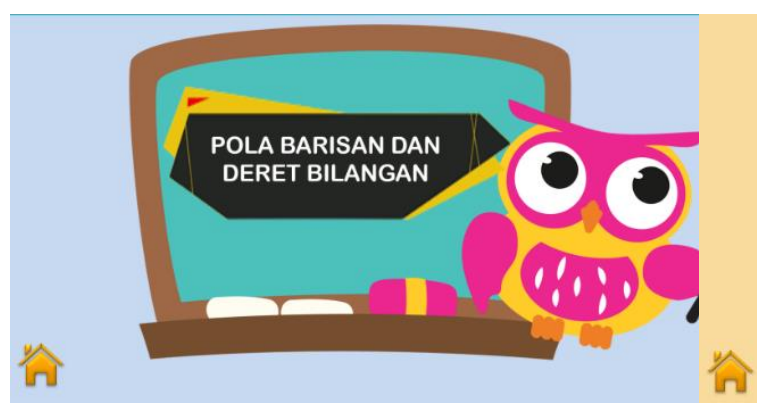

Gambar 6. Tampilan Awal materi pola barisan dan deret bilangan

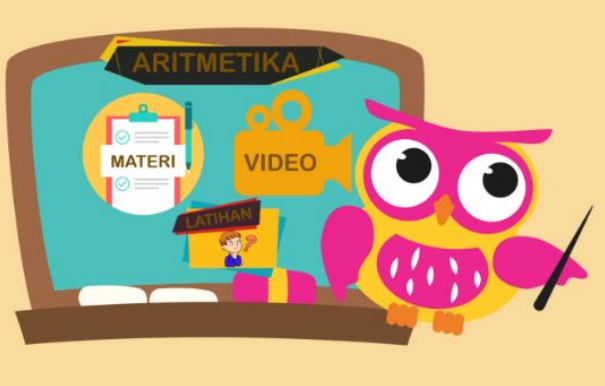

Gambar 7. Menu Sub Bab Materi 


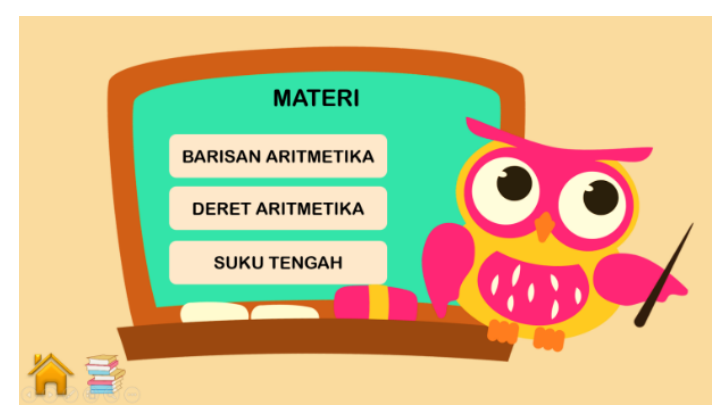

Gambar 8. Pilihan Materi

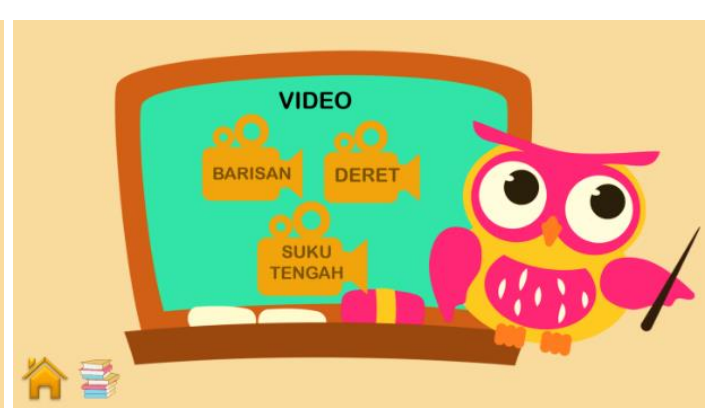

Gambar 9. Pilihan Video

Selanjutnya ketika memilih menu video maka akan ditujuan ke halaman pilihan video yang terdiri dari video materi 1, 2 dan seterusnya, terkecuali jika dalam sub bab tersebut hanya terdiri dari satu materi maka akan langsung ditujukan ke video yang dituju. Berikut adalah menu pilihan video yang ditunjukan pada Gambar 9. Kemudian ketika memilih menu latihan pada Gambar 7 di atas maka akan ditunjukan pada halaman latihan dan peserta didik dapat langsung mengumpulkan jawaban dengan mengklik icon send answer seperti pada Gambar 10 berikut. Kemudian jika memilih salah satu materi yang terdapat pada Gambar 8 maka akan ditujukan ke halaman yang berisi materi dan contoh dan penyelesaian seperti pada Gambar 11. Materi disesuaikan dengan KD pada materi barisan dan deret, dan contoh soal disesuaikan dengan indikator berpikir komputasional yaitu berpikir algoritma, dekomposisi, pengenalan pola dan genearlisasi pola dan abstraksi. Selanjutnya jika memilih salah satu video seperti pada Gambar 9 maka akan ditujukan ke video sesuai dengan materi yang dipilih seperti pada gambar 12. Ketika memilih icon send answer pada Gambar 10 maka akan ditujukan ke sebuah form pengumpulan tugas seperti pada Gambar 13.

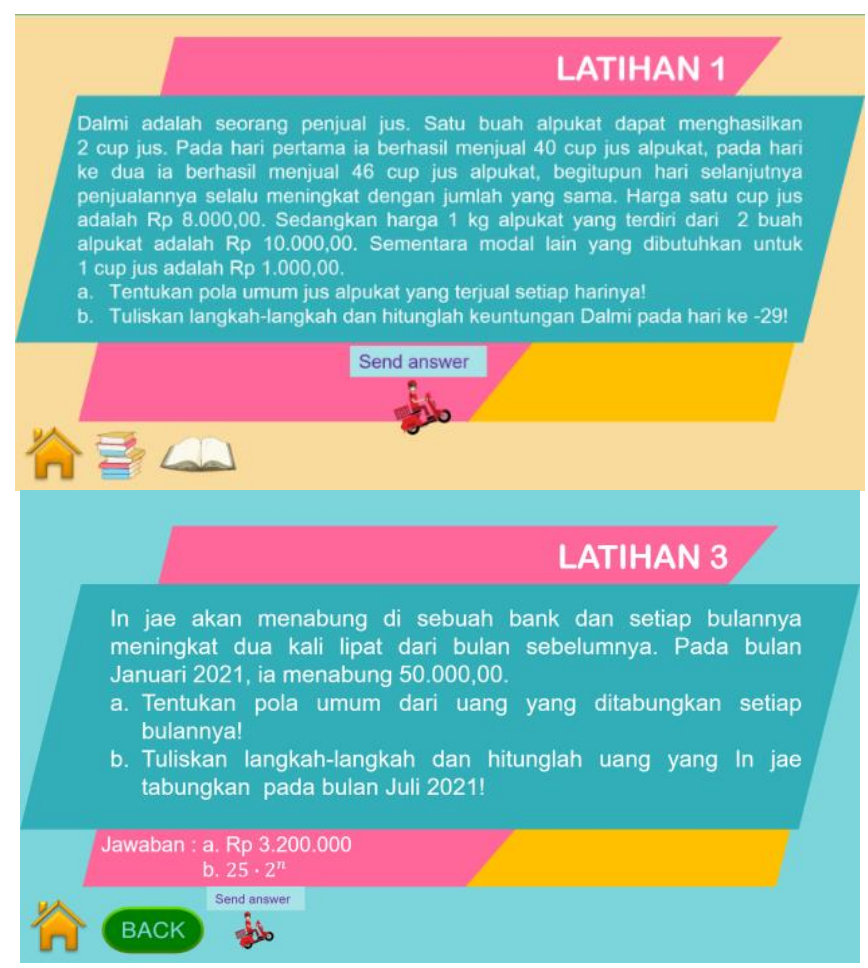

Gambar 10. Tampilan Halaman Latihan 


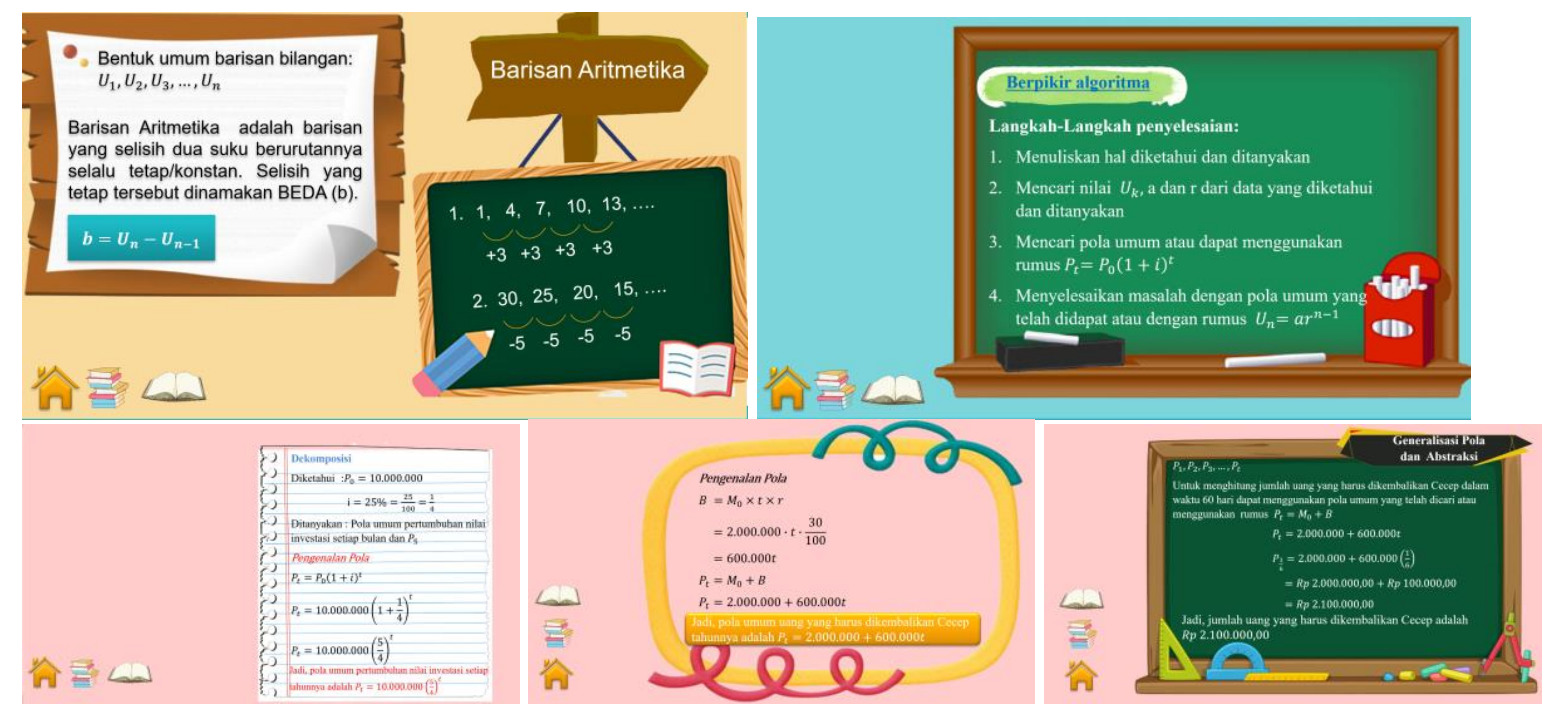

Gambar 11. Contoh Halaman Materi dan Conoh Soal

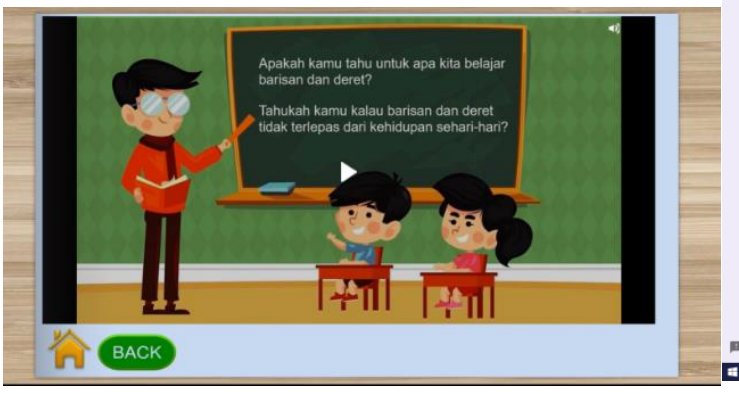

Gambar 12. Salah Satu Tampilan Video

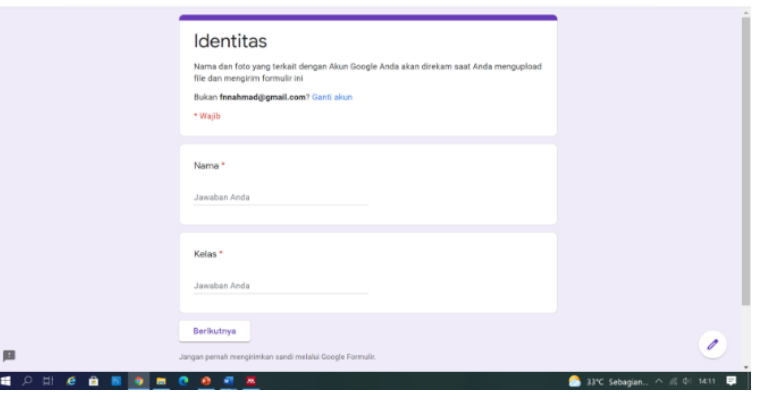

Gambar 13. Form Pengumpulan Jawaban

Setelah selesai, digibook tersebut divalidasi oleh 2 ahli media dan 2 ahli materi. Validasi oleh ahli media 1 dilakukan sebanyak dua kali, sementara validasi oleh ahli media dosen 2 hanya satu kali. Sedangkan validasi oleh ahli materi 1 dan 2 dilakukan hanya satu kali.

Pada validasi tahap ke-1, validator ahli media 1 memberikan kesimpulan penilaian secara umum "dapat digunakan tanpa perbaikan". Sementara validator 2 ahli media memberikan kesimpulan penilaian secara umum "dapat digunakan dengan perbaikan". Hal yang harus diperbaiki dari ahli media 2 adalah memperbaiki gambar yang menutupi teks, kemudian beberapa audio yang tidak sesuai dengan isi materi. Kemudian digibook direvisi sesuai koreksi dan masukan dari validator dan memberikan kesimpulan "dapat digunakan tanpa perbaikan". Secara keseluruhan hasil validasi oleh ahli media dan ahli materi memberikan kesimpulan "dapat digunakan tanpa perbaikan" sehingga dapat dilanjutkan ke tahap implementasi.

\section{Implementation (Implementasi)}

Setelah produk dinyatakan valid dan dapat digunakan tanpa perbaikan, langkah selanjutnya adalah implemetasi. Tahap implementasi ini dilakukan sebanyak dua kali yaitu uji coba perorangan dan uji coba terbatas di SMAN 1 Talaga. Uji coba perorangan dilakukan terhadap 5 orang peserta didik dan 3 orang guru. Kemudian masing-masing peserta didik dan guru diberikan angket respon pengguna. Pada uji coba perorangan peserta didik tersebut diperoleh skor total sebesar 166 dengan 
interpretasi "baik". Sedangkan, uji coba perorangan guru matematika memperoleh skor total 109 dngan interpretasi "sangat baik". Setelah itu, peneliti melakukan uji coba terbatas diperoleh skor total 669 dengan interpretasi "baik".

\section{Evaluation (Evaluasi)}

Tahap terakhir adalah evaluation (evaluasi). Hasil akhir dari penelitian ini adalah menghasilkan suatu produk digibook barisan dan deret untuk mengeksplor berpikir komputasional yang valid dan dapat digunakan sebagai sumber belajar. Digibook ini diharapkan dapat meningkatkan motivasi belajar peserta didik dan dapat memudahkan peserta didik untuk belajar secara mandiri.

Selanjutnya peneliti mengukur kualitas efektivitas berpikir komputasional setelah menggunakan digibook barisan dan deret dengan menggunakan nilai pretest dan posttest. Pretest dilakukan sebelum peneliti memberikan digibook untuk mengukur kemampuan awal peserta didik. Kemudian setelah itu peserta didik diberikan digibook yang digunakan sebagai sumber belajar. Setelah peserta didik belajar menggunakan digibook barisan dan deret, peneliti memberikan posttest untuk melihat kemampuan akhir peserta didik setelah belajar menggunakan digibook. Untuk mengukur kualitas efektivitas digunakan rumus Effevt Size. Menurut Cohen (1992) dalam mengukur effect size yaitu dengan membandingkan dua kondisi dengan mengurangi salah satu kondisi dengan kondisi lainnya dan hasilnya dibagi dengan simpangan baku. Sesuai dengan pernyataan York (2020) yang menyatakan bahwa rumus Effect Size digunakan untuk menganalisis data satu kelompok dengan nilai pretest dan posttest dengan cara mengambil selisih antara rata-rata nilai posttest dan rata-rata nilai pretest dan membagi angka tersebut dengan standar deviasi dari nilai pretest. Dari hasil pretest dan postest diperoleh data berikut.

$m_{A}=80,75$

$m_{B}=67,25$

$\sigma=13,12641$

$E S=\frac{m_{A}-m_{B}}{\sigma}$

$E S=\frac{80,75-67,25}{13,12641}$

$E S=1,03$

Berdasarkan hasil perhitungan effect size 1.03 termasuk ke dalam kriteria strong effect (L. Cohen et al., 2007). Artinya, digibook barisan dan deret yang dikembangkan dapat mengeksplor berpikir komputasional peserta didik dan menjadi sumber belajar baru yang menarik bagi peserta didik.

\section{KESIMPULAN}

Berdasarkan penelitian dan pengembangan diperoleh kesimpulan yaitu: (1) Digibook barisan dan deret untuk mengeskplor berpikir komputasional peserta didik telah dikembangkan dengan 
menggunakan model ADDIE yang terdiri dari 5 tahapan yaitu: (a) Analyze (analisis), pada tahap ini peneliti melakukan analisis media pembelajaran, materi pelajaran, peserta didik dan guru (b) Design (perancangan), pada tahap ini peneliti membuat flowchart, dan membuat storyboard, mempersiapkan instrument tes, lembar validasi ahli media dan ahli materi, dan angket respon pengguna. (c) Develop (pengembangan), pada tahap ini menghasilkan produk sesuai rancangan, melakukan uji ahli media, dan uji ahli materi, (d) Impelementation (implementasi), pada tahap ini melakukan uji coba perorangan dan uji coba terbatas dan mendapatkan kategori "baik". (e) Evaluation (evaluasi), pada tahap ini melakukan penyempurnaan produk apabila masih terdapat kekurangan dan kelemahan. (2) Kualitas efektivitas berpikir komputasional setelah menggunakan digibook barisan dan deret memperoleh nilai ES sebesar 1,028460866 dengan kategori strong effect.

\section{REFERENSI}

Angriani, A. D., Kusumayanti, A., \& Yuliany, N. (2020). Pengembangan Media Pembelajaran Digital Book pada Materi Aljabar. 9(2), 13-30.

Asbell-Clarke, J., Rowe, E., Almeda, V., Edwards, T., Bardar, E., Gasca, S., Baker, R. S., \& Scruggs, R. (2021). The development of students' computational thinking practices in elementary- and middle-school classes using the learning game, Zoombinis. Computers in Human Behavior, 115, 106587. https://doi.org/10.1016/j.chb.2020.106587

Asmuni, A. (2020). Problematika Pembelajaran Daring di Masa Pandemi Covid-19 dan Solusi Pemecahannya. Jurnal Paedagogy, 7(4), 281. https://doi.org/10.33394/jp.v7i4.2941

Branch, R. M. (2010). Instructional design: The ADDIE approach. In Instructional Design: The ADDIE Approach. https://doi.org/10.1007/978-0-387-09506-6

Cahdriyana, R. A., \& Richardo, R. (2020). Berpikir Komputasi Dalam Pembelajaran Matematika. LITERASI (Jurnal Ilmu Pendidikan), 11(1), 50. https://doi.org/10.21927/literasi.2020.11(1).5056

Cohen, J. (1992). Statistical Power Analysis. Current Directions in Psychological Science, 1(3), 98101.

Cohen, L., Manion, L., \& Morrison, K. (2007). Experiments, quasi-experiments, single-case research and meta-analysis. In Research Methods in Education. https://doi.org/10.4324/978020302905323

Fajri, M., Yurniawati, \& Utomo, E. (2019). Computational Thinking , Mathematical Thinking Berorientasi Gaya Kognitif Pada Pembelajaran Matematika Di Sekolah Dasar. Dinamika Matematika Sekolah Dasar 1 (1), 1-18, 1(1), 1-18.

Firdaus, A., Nisa, L. C., \& Nadhifah, N. (2019). Kemampuan Berpikir Kritis Siswa pada Materi Barisan dan Deret Berdasarkan Gaya Berpikir. Kreano, Jurnal Matematika Kreatif-Inovatif, 10(1), 68-77. https://doi.org/10.15294/kreano.v10i1.17822 
Hasanah, H., Nugraheni, P., \& Purwoko, R. Y. (2020). Analisis Kendala Penerapan Pendekatan Saintifik dalam Pembelajaran Barisan dan Deret Geometri. Kreano, Jurnal Matematika KreatifInovatif, 11(1), 16-26. https://doi.org/10.15294/kreano.v11i1.20663

Lei, H., Chiu, M. M., Li, F., Wang, X., \& Geng, Y. jing. (2020). Computational thinking and academic achievement: A meta-analysis among students. Children and Youth Services Review, 118(June), 105439. https://doi.org/10.1016/j.childyouth.2020.105439

Munandar, A., \& Rizki, S. (2019). Pengembangan Bahan Ajar Matematika Berbasis Komputer Menggunakan Flipbook Maker Disertai Nilai Islam Pada Materi Peluang. AKSIOMA: Jurnal Program Studi Pendidikan Matematika, 8(1), 262-269. https://doi.org/10.24127/ajpm.v8i1.1957

Nopriana, T., Firmasari, S., \& Tonah, T. (2016). Desain Bahan Ajar Berbasis Aktivitas Pemecahan Masalah Pada Pokok Bahasan Barisan Dan Deret. Euclid, 2(2), 251-263. https://doi.org/10.33603/e.v2i2.361

Patmawati, H., Ratnaningsih, N., \& Hermanto, R. (2016). Developing Character Based Interactive L Earning Media To Facilitate Student' S Self - Learning of Capita Selecta Mathematics ( a Research on Mathematical Critical and Creative Thinking Skillsof Mathematics Departement Studentof Teacher Trainingand Educa. 1(2008), 523-532.

Pixyoriza, Netriwati, \& Sugiharta, I. (2019). Pengembangan Media Pembelajaran Digital Book Menggunakan Kvisoft Flipbook Berbasis Problem Solving. 5(1), 31-39.

Ratnaningsih, N. (2016). Development Interactive Learning Media to Excavate Ability Mathematical Creative Thinking Students. Prosiding Seminar Internasional FKIP UNY, May, 16-17.

Ratnaningsih, N., Ni'Mah, K., \& Hidayat, E. (2021). Covid-19 the Earliest for Digital Learning in Mathematics: An Overview from Technology Literacy. Journal of Physics: Conference Series, 1819(1). https://doi.org/10.1088/1742-6596/1819/1/012027

Sanusi, A. M., Septian, A., \& Inayah, S. (2020). Kemampuan Berpikir Kreatif Matematis dengan Menggunakan Education Game Berbantuan Android pada Barisan dan Deret. Mosharafa: Jurnal Pendidikan Matematika, 9(3), 511-520.

Sari, A. S. (2016). PENGEMBANGAN BUKU DIGITAL MELALUI APLIKASI SIGIL ( The Development of Digital Book through Sigil Application in Cookies and Candys Lessons ). 1(2), $46-54$.

Setyadi, D., \& Qohar, A. (2017). Pengembangan Media Pembelajaran Matematika Berbasis Web Pada Materi Barisan Dan Deret. Kreano, Jurnal Matematika Kreatif-Inovatif, 8(1), 1-7. https://doi.org/10.15294/kreano.v8i1.5964

Sopian, Y. A., \& Afriansyah, E. A. (2017). Kemampuan Proses Pemecahan Masalah Matematis Siswa melalui Model Pembelajaran Creative Problem Solving dan Resource Based Learning (Studi Eksperimen pada Siswa Kelas X SMK Krija Bhakti Utama Limbangan). Jurnal Elemen, 3(1), 97. https://doi.org/10.29408/jel.v3i1.317 
Taber, K. S. (2018). Scaffolding learning: Principles for effective teaching and the design of classroom resources. Effective Teaching and Learning: Perspectives, Strategies and Implementation, March, 1-44.

York, R. O. (2020). Statistics for Human Service Evaluation. Statistics for Human Service Evaluation, 75-96. https://doi.org/10.4135/9781071801024

Zhong, B., Wang, Q., Chen, J., \& Li, Y. (2016). An exploration of three-dimensional integrated assessment for computational thinking. Journal of Educational Computing Research, 53(4), 562-590. https://doi.org/10.1177/0735633115608444 